\title{
Produktivitas Broiler yang Diberikan Infusa Daun Pepaya (Carica papaya $L_{\text {.) }}$
}

\section{Infusion of Papaya (Carica papaya L.) Leaves on Broiler Productivity}

\author{
A K Rylian ${ }^{1}$, N Irwani ${ }^{1 *}$, dan Y Sukaryana ${ }^{1}$ \\ ${ }^{1}$ Jurusan Peternakan Politeknik Negeri Lampung, \\ Jln. Soekarno Hatta No 10 Rajabasa Bandar Lampung, 35144 \\ *E-mail korespondensi : naniirwani@polinela.ac.id
}

\begin{abstract}
One of the efforts to improve broiler productivity is to use natural ingredients, one of which is papaya leaves. Papaya leaves contain substances such as saponins, flavonoids, which can help productivity. The purpose of this study was to analyze the effect of papaya leaf infusion on broiler productivity. Place of research in the Lampung State Polytechnic enclosure. Experimental research by comparing two treatments. The treatment is applied through drinking water at a dose of $25 \mathrm{ml} /$ liter. Consisting of control PO and treatment P1, each plot contains 50 chickens. The variables observed were ration consumption, body weight gain, ration conversion, it can be concluded from the results of the research that giving papaya leaf infusion (Carica Papaya L.) at a dose of $25 \mathrm{ml} /$ liter in broiler drinking water affected the productivity of broiler.
\end{abstract}

Keywords: Broiler productivity, Infusion, papaya

Diterima: 1 Juli 2021., disetujui 15 Desember 2021

\section{PENDAHULUAN}

Penduduk Provinsi Lampung semakin bertambah tiap tahunnya yaitu pada tahun 2019 sebesar 8.447.737 jiwa atau meningkat $1 \%$ dari tahun sebelumnya (BPS, 2020). Jumlah konsumsi protein hewani Provinsi Lampung meningkat pada tahun 2019 sebesar 85.558.337 ekor atau meningkat 6,3\% dari tahun sebelumnya (Munawar, 2019). Masyarakat mulai menyadari bahwa mengkonsumsi protein hewani sangat penting untuk pemenuhan gizi.

Daging ayam merupakan salah satu sumber protein hewani yang paling banyak dikonsumsi oleh masyarakat karena cita rasanya yang enak dan kandungan gizinya yang tinggi. Komposisi gizi pada daging ayam per 100 gram mengandung protein $18,20 \mathrm{~g}$, lemak 25,00 g, kalsium 14,00 mg, fosfor 200,00 mg, besi 1,50 mg, vitamin B1 0,08 mg, air 55,90 g dan kalori 302,00 kkal (Ditjenak, 2019).

Ayam broiler merupakan salah satu produk unggulan karena pertumbuhannya yang sangat cepat sehingga menghasilkan daging dengan waktu yang relatif singkat yaitu dalam 3 sampai 4 minggu sudah bisa dipanen (Rasyaf, 2008). Broiler memiliki kelebihan seperti pertumbuhan yang cepat, dan banyak digemari oleh masyarakat. Pertumbuhan broiler perlu diperhatikan nutrisinya pakan sehingga dapat meningkatkan produktivitas.

Penambahan feed additive sering diberikan pada pemeliharaan broiler untuk meningkatkan efisiensi pakan dan produksi, penggunaan Antibiotic Growth Promotor (AGP) merupakan antibiotik yang digunakan pada pakan untuk mempercepat pertumbuhan. Pelarangan penggunaan AGP berdampak pada bobot badan broiler yang dapat menurun (Fati et al., 2020). Pencegahan penggunaaan AGP dilakukan dengan menggunakan bahan alami, salah satunya daun pepaya 
Daun pepaya memiliki kandungan senyawa seperti saponin, flavonoid, terpenoid, namun hal tersebut masih perlu dibuktikan pengaruhnya untuk produktivitas broiler. Untuk itu, penulis tertarik untuk menggunakan daun pepaya yang diekstraksi sebagai feed additive dengan metode infusa pada produktivitas broiler.

\section{METODE PENELITIAN}

\section{Alat dan Bahan}

Penelitian ini dilaksanakan di Kandang Jurusan Peternakan Politeknik Negeri Lampung. Ayam yang digunakan pada penelitian ini adalah MB 202 dari PT. Japfa Comfeed sebanyak 100 ekor yang dipelihara selama 28 hari. Ransum yang digunakan pada penelitian ini yaitu ransum komersil BR-I dan BR-II produksi PT. Japfa Comfeed yang diberikan secara adlibitum. Air minum yang digunakan dalam penelitian ini berupa air yang ada di sekitar kandang dan diberikan secara adlibitum.

\section{Pembuatan Infusa Daun Papaya}

Pembuatan infusa dilakukan dengan mengikuti metode Kunariah et al., (2016) yaitu dengan cara : menyiapkan daun pepaya yang tidak terlalu tua 1 sampai 2 lembar, mencuci daun pepaya setelah itu dipotongpotong lalu ditimbang sebanyak 100 gram, masukkan daun pepaya ke dalam bejana infus, menambahkan aquadestilata sebanyak $100 \mathrm{ml}$ dan dimasukkan ke dalam waterbath, memanaskan daun pepaya selama 15 menit terhitung mulai suhu mencapai $90^{\circ} \mathrm{C}$, selama proses pemanasan sesekali diaduk kemudian disaring menggunakan kain flanel, menampung cairan dan diukur filtrat yang diperoleh, ampas yang tertinggal disaring kembali, ditambahkan aquadestilata, menyaring kembali larutan dan dicukupkan hingga $100 \mathrm{ml}$.

\section{Metode Kerja}

Pemberian infusa diberikan saat memasuki usia 2 minggu (hari ke-8) pada pagi hari sampai hari ke-28, ayam terlebih dahulu dipuasakan selama 2 jam agar merasa haus lalu diberikan infusa daun pepaya dengan dosis $25 \mathrm{ml} /$ liter, dilakukan pencampuran bersama dengan setengah dari kebutuhan air minum sesuai dengan umur broiler. Lama pemberian infusa sampai air yang diberikan habis setelah itu air minum diganti dengan air putih kembali.

Broiler dipelihara seperti biasa sampai umur 1 minggu, saat memasuki usia 2 minggu (hari ke-8) ayam pisah menjadi 2 kelompok, kelompok P0 dipelihara seperti biasa tanpa pemberian perlakuan, kelompok P1 diberikan perlakuan infusa daun pepaya, setiap minggu dilakukan pengukuran konsumsi ransum, pertambahan bobot badan untuk mengetahui konversi ransum.

Perlakuan dosis ekstrak daun pepaya yaitu :

PO : tanpa pemberian perlakuan.

$\mathrm{P} 1$ : diberikan perlakuan infusa daun pepaya $25 \mathrm{ml} / \mathrm{liter}$.

\section{Peubah yang Diamati}

Peubah yang diamati meliputi:

1. Konsumsi ransum

Pengukuran konsumsi ransum (g/ekor/hari) dengan menghitung selisih antara jumlah ransum yang diberikan dengan jumlah ransum sisa dan diukur setiap hari selama pemeliharaan (Firdaus et al., 2017). Konsumsi ransum (g/ekor/hari) = jumlah yang diberikan - jumlah sisa.

2. Pertambahan bobot badan

Pengukuran pertambahan bobot badan (g/ekor/minggu) dihitung dengan mengurangi berat akhir dengan berat awal yang dilakukan setiap minggu (Firdaus et al., 2017). Perhitungan dilakukan selama empat minggu dengan menimbang setiap ekor ayam. 
Pertambahan bobot badan (g/ekor/minggu) $=$ berat bobot akhir - berat bobot awal .

3. Konversi ransum (Feed Convertion Ratio)

Perbandingan jumlah konsumsi ransum pada satu minggu dengan pertambahan bobot badan yang dicapai selama satu minggu selama pemeliharaan (Kartadisastra, 1994) perhitungan dilakukan setiap minggu sampai minggu keempat.

Konversi Ransum $=\frac{\text { jumlah ransum yang di konsumsi }(\mathrm{g} / \mathrm{ekor})}{\text { pertambahan bobot badan }(\mathrm{g} / \mathrm{ekor})}$

\section{Analisis Data}

Penelitian dilakukan secara eksperimen melihat respon perlakuan. Perlakuan yang diterapkan adalah pemberian infusa daun pepaya pada air minum dengan dosis $25 \mathrm{ml} /$ liter dilakukan pemberian pada saat memasuki usia 2 minggu (hari ke-8). Data yang diperoleh dari hasil penelitian dilakukan pengujian dengan menggunakan uji t.

\section{HASIL DAN PEMBAHASAN}

Berdasarkan hasil penelitian, pemberian infusa daun pepaya dengan dosis $25 \mathrm{ml} / \mathrm{liter}$ air minum menunjukkan adanya perbedaan produktivitas. Produktivitas broiler meliputi konsumsi ransum, pertambahan bobot badan, dan konversi ransum disajikan pada Tabel 1.

Tabel 1 Produktivitas Ayam Broiler yang Diberikan Infusa Daun Papaya

\begin{tabular}{lrr}
\hline & \multicolumn{1}{c}{ P0 } & \multicolumn{1}{c}{ P1 } \\
\hline Konsumsi Ransum (g/ekor) & 1855,36 & 1807,65 \\
Pertambahan Bobot Badan (g/ekor) & 1313,13 & 1356,53 \\
Konversi Ransum & 1,41 & 1,33 \\
\hline
\end{tabular}

Keterangan : $\quad \mathrm{P} 0=$ kontrol

$\mathrm{P} 1=$ infusa daun papaya

\section{Konsumsi Ransum}

Pemberian infusa daun pepaya dalam air minum berbeda jumlah konsumsinya. Konsumsi ransum pada broiler yang diberi infusa daun pepaya terdapat selisih dengan konsumsi ransum broiler yang tidak diberikan infusa sebanyak 47,71 g, hal ini dikarenakan rasa dari infusa daun pepaya yang pahit sehingga menurunkan nafsu makan tetapi pemberian infusa yang dilakukan secara rutin maka broiler menjadi terbiasa. Ayam tidak menyukai rasa pahit pada saat awal pemberian infusa daun pepaya sehingga konsumsinya sedikit dibanding kontrol, setelah terbiasa maka konsumsinya akan seperti biasa (Hasiib et al., 2015). Hal ini disebabkan oleh kandungan saponin pada daun pepaya yang bersifat antibakteri sehingga menghambat pertumbuhan bakteri pada saluran pencernaan sehingga memanfaatkan pakan yang dikonsumsi menjadi efisien. Senyawa terpenoid membantu dalam proses pencernaan sehingga proses optimalisasi pencernaan lemak dan amilum mengakibatkan sifat lapar menjadi rendah sehingga berpengaruh pada konsumsi ransum (Hasiib et al., 2015).

\section{Pertambahan Bobot Badan}

Pertambahan bobot badan broiler yang diberi infusa daun pepaya berbeda dengan broiler yang tidak diberikan infusa daun pepaya yang berarti perlakuan pemberian infusa daun pepaya berpengaruh terhadap pertambahan bobot badan sebesar 1356,53 g/ekor. Daun pepaya mengandung saponin, yang bersifat seperti sabun (berbusa) yang menghambat pembentukan dinding sel bakteri pada dinding usus sehingga mudah lisis. Hal ini akan mempermudah penyerapan molekul-molekul besar dalam tubuh, sehingga dapat berpengaruh 
pada pertambahan bobot badan dan proses metabolisme lemak dalam tubuh diubah menjadi daging sehingga konversi ransum rendah dan meningkatkan pertambahan bobot badan (Khodijah et al., 2012).

\section{Konversi Ransum}

Konversi ransum pada broiler yang diberikan perlakuan infusa daun pepaya lebih rendah dari pada kontrol, perlakuan pemberian infusa daun pepaya berpengaruh terhadap konversi ransum sebesar 1,33. Standar konversi ransum strain MB 202 umur 4 minggu 1,41 (Japfa Comfeed Indonesia, 2012).

Penggunaan infusa daun pepaya mampu mengefisiensi ransum karena senyawa yang terkandung dalam daun pepaya untuk membantu proses metabolisme pakan yang dikonsumsi sehingga proses penyerapan yang baik yang ditandai pertambahan bobot badan yang berbeda dengan kontrol. Daun pepaya mengandung senyawa saponin dan flavonoid yang dapat membantu metabolisme dalam tubuh, sehingga ransum yang dikonsumsi dimafaatkan untuk pertumbuhan (Irwani dan Candra, 2016)

\section{KESIMPULAN}

Pemberian infusa daun pepaya (Carica Papaya $L$ ) dengan dosis pemberian $25 \mathrm{ml} /$ liter dalam air minum broiler mampu meningkatkan produktifitas ayam broiler dengan menurunkan nilai konversi ransum.

\section{DAFTAR PUSTAKA}

Badan Pusat Statistik (BPS). 2020. Provinsi Lampung dalam Angka Lampung. Lampung. BPS Provinsi Lampung.

Direktorat Jenderal Peternakan dan Kesehatan Hewan (Ditjennak). 2019. Statistik Peternakan dan Kesehatan Hewan 2019. Direktorat Jenderal Peternakan dan Kesehatan Hewan Kementrian Pertanian RI: Jakarta.

Hasiib, E.A., Riyanti, R. dan Hartono, M. 2015. Pengaruh pemberian ekstrak daun binahong (Anredera cordifolia (Ten.) Steenis) dalam air minum terhadap performa broiler. Jurnal Ilmiah Peternakan Terpadu 3(1): 14-22.

Irwani, N. dan Candra, A.A. 2016. Ekstrak daun gedi (Abelmoschus manihot) pada ayam broiler. Jurnal Pengembangan Teknologi Pertanian, 281-285.

Japfa Comfeed Indonesia. 2012. Manual Production MB 202 (Pedaging) dan MB 402 (Petelur). Poultry breeding division. Jakarta.

Firdaus, J., Kurtini, T., dan Riyanti R. 2017. Pengaruh pemberian jamu tradisional dalam air minum terhadap performa broiler. Jurnal Riset dan Inovasi Peternakan 1(2): 22-27.

Khodijah, E. S., Abun dan Wiradimadja, R. 2012. Imbangan efisiensi protein broiler yang diberi ransum mengandung ekstrak kulit jengkol (Pithecellobium jiringa (Jack) Prain). Student E-Jurnal 1(1): 1-6.

Kunariah, S., Purnomo, H. D., dan Fajaryanti, N. 2016. Pengaruh pemberian infusa daun pepaya (Carica papaya $L$.) terhadap efek daya analgetik pada hewam uji mencit (Mus musculul L.) yang terpapar asam asetat pepaya (Carica papaya L.) diuji untuk membuktikan adanya efek daya analgetik. Jurnal Farmasetis, 5(1): 28-32.

Rasyaf, M. 2008. Panduan Beternak Ayam Pedaging. Jakarta: Penebar Swadaya. 